\title{
The Burden of Peritoneal Metastases from Gastric Cancer: A Systematic Review on the Incidence, Risk Factors and Survival
}

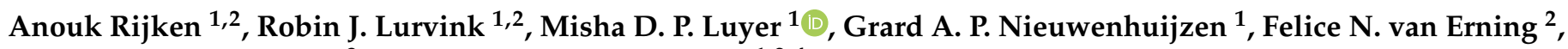 \\ Johanna W. van Sandick ${ }^{3}$ and Ignace H. J. T. de Hingh ${ }^{1,2,4, *}$ \\ 1 Department of Surgery, Catharina Cancer Institute, Catharina Hospital, \\ 5602 ZA Eindhoven, The Netherlands; anouk.rijken@catharinaziekenhuis.nl (A.R.); \\ robin.lurvink@catharinaziekenhuis.nl (R.J.L.); misha.luyer@catharinaziekenhuis.nl (M.D.P.L.); \\ grard.nieuwenhuijzen@catharinaziekenhuis.nl (G.A.P.N.) \\ 2 Department of Research and Development, Netherlands Comprehensive Cancer Organization, \\ 3511 DT Utrecht, The Netherlands; f.vanerning@iknl.nl \\ 3 Department of Surgery, Antoni van Leeuwenhoek-Netherlands Cancer Institute, \\ 1066 CX Amsterdam, The Netherlands; j.v.sandick@nki.nl \\ 4 GROW—School for Oncology and Development Biology, Maastricht University, \\ 6229 ER Maastricht, The Netherlands \\ * Correspondence: ignace.d.hingh@catharinaziekenhuis.nl; Tel.: +31-40-239-7150
}

Citation: Rijken, A.; Lurvink, R.J.; Luyer, M.D.P.; Nieuwenhuijzen, G.A.P.; van Erning, F.N.; van Sandick, J.W.; de Hingh, I.H.J.T. The Burden of Peritoneal Metastases from Gastric Cancer: A Systematic Review on the Incidence, Risk Factors and Survival. J. Clin. Med. 2021, 10, 4882. https:// doi.org/10.3390/jcm10214882

Academic Editors:

Santiago Gonzalez-Moreno and Gloria Ortega-Perez

Received: 10 September 2021

Accepted: 21 October 2021

Published: 23 October 2021

Publisher's Note: MDPI stays neutral with regard to jurisdictional claims in published maps and institutional affiliations.

Copyright: (c) 2021 by the authors. Licensee MDPI, Basel, Switzerland. This article is an open access article distributed under the terms and conditions of the Creative Commons Attribution (CC BY) license (https:// creativecommons.org/licenses/by/ $4.0 /)$.

\begin{abstract}
The peritoneum is a common metastatic site in gastric cancer. This systematic review provides an overview of the incidence, risk factors and survival of synchronous peritoneal metastases from gastric cancer. A systematic search was performed to identify studies wherein the incidence, risk factors and survival of gastric cancer with peritoneal metastases were investigated. Of all 38 potentially eligible studies, 17 studies were included based on the eligibility criteria. The incidence of synchronous gastric peritoneal metastases was reviewed for population-based studies (10-21\%), for observational cohort studies (2-15\%) and for surgical cohort studies (13-40\%). Potential risk factors for synchronous gastric peritoneal metastases were younger age, non-cardia gastric cancer, female sex, signet ring cell carcinoma, diffuse type histology or linitis plastica, T4 stage, Hispanic ethnicity and more than one metastatic location. Synchronous peritoneal metastases are commonly diagnosed in patients with gastric cancer with an incidence up to $21 \%$ in recent population-based studies. Furthermore, prognosis of patients with gastric peritoneal metastases is poor with median overall survival ranging from 2 to 9 months. The high incidence and poor prognosis require intensive research on diagnostic features and effective treatment options to improve survival.
\end{abstract}

Keywords: peritoneal metastases; gastric cancer; incidence; treatment; survival

\section{Introduction}

Gastric cancer is one of the most common cancers worldwide with an incidence of over one million cases in 2020. It is the third most common cause of cancer-related death in the world, with almost 800,000 deaths a year [1]. Among Asian men, gastric cancer is even the most commonly diagnosed cancer and the leading cause of cancer death [2]. Due to the lack of early symptoms, patients with gastric cancer are often diagnosed in an advanced stage, which generally leads to a poor prognosis [3].

The peritoneal cavity is a well-known metastatic site in gastric cancer. For a long time, patients with isolated peritoneal metastases regardless of their origin had a dismal prognosis, and therapeutic options were scarce. However, several studies investigating the effect of cytoreductive surgery (CRS) and hyperthermic intraperitoneal chemotherapy (HIPEC) in patients with gastric, colorectal and ovarian peritoneal metastases have suggested an improvement in survival in carefully selected patients [4-7]. A randomised controlled trial (PERISCOPE II, NCT03348150) currently enrols gastric cancer patients with isolated limited peritoneal metastases to investigate whether CRS-HIPEC provides a 
survival benefit compared to systemic chemotherapy alone [8,9]. For patients with more extensive disease, new therapeutic options such as pressurized intraperitoneal aerosol chemotherapy (PIPAC) or normothermic intraperitoneal chemotherapy are being studied in clinical trials $[10,11]$. Awaiting the results of these trials, the current standard treatment in the Netherlands for this patient group remains palliative systemic chemotherapy, although the beneficial effect of current chemotherapeutic regimens is probably limited [12]. In patients with HER2-positive gastric cancer, the addition of trastuzumab may be considered as the randomised controlled ToGa-trial showed that this prolonged survival in advanced gastric cancer as compared to systemic chemotherapy alone [13].

The evolution and refinement of new techniques such as CRS-HIPEC, PIPAC and normothermic intraperitoneal chemotherapy have generated a renewed interest in the treatment of gastric peritoneal metastases. However, the burden of peritoneal metastases from gastric cancer is currently not well described. Detailed information on this topic will be helpful in counselling of patients and will guide future research directions. Especially, knowledge about risk factors for peritoneal metastases and the impact of survival may contribute to a tailored approach in treatment of patients with gastric cancer. The aim of this systematic review was to provide an overview of the incidence, risk factors and survival of gastric cancer with peritoneal metastases.

\section{Materials and Methods}

This systematic review was reported according to the Preferred Reporting Items for Systematic Reviews and Meta-Analyses (PRISMA) statement [14]. Two researchers (A.R. and R.J.L.) independently performed the literature search, study selection, data collection, risk of bias assessment and data synthesis. Inter-reviewer disagreements were resolved by achieving consensus between the two researchers.

\subsection{Eligibility Criteria}

Studies were considered potentially eligible if: (1) patients with gastric cancer were included and (2) the incidence, risk factors and/or survival of synchronous peritoneal metastases were analysed in the setting of a population-based or observational cohort. Furthermore, in a specific subgroup, studies were considered potentially eligible if patients who underwent diagnostic laparoscopy for staging of gastric cancer were investigated. Studies reporting on incidence were considered eligible if synchronous peritoneal metastases were reported as the proportion of all patients with gastric cancer. Studies reporting on risk factors were considered eligible if: (1) multivariable regression analyses were performed and (2) an odds ratio or relative risk were reported as outcome measure. Furthermore, studies reporting exclusively on patients with gastro-oesophageal junction cancer, case-reports, systematic reviews and studies with a publication year before 2000 were excluded. No language restrictions were applied.

\subsection{Search Strategy}

On 15 August 2021, PubMed/MEDLINE, EMBASE and Cochrane were systematically searched with a date restriction from 2000 to 2021. Full search queries are presented in Appendix A. The references of all eligible manuscripts were searched for additional eligible studies.

\subsection{Study Selection}

Titles and abstracts were screened for potentially eligible studies based on the predefined eligibility criteria. Afterwards, all potentially eligible studies were thoroughly read screened for final inclusion.

\subsection{Data Collection}

Data were collected by two researchers (A.R. and R.J.L.) using a standardised form that contained the following items: year of publication, study design, study setting, country, 
enrolment period, total number of patients, study population and the three outcomes under investigation (incidence, risk factors and survival).

\subsection{Synthesis of Results}

Results of all studies considered eligible were descriptively presented. Due to the high degree of heterogeneity across the included studies (i.e., study design, differences in study population), no meta-analysis was performed.

\section{Results}

\subsection{Study Selection}

After title and abstract screening, 38 studies were considered potentially eligible. After full text screening, seventeen studies were included [12,15-30]. The study flowchart and reasons for exclusion are shown in Figure 1 and Appendix B. In sixteen studies, information on incidence numbers of synchronous gastric peritoneal metastases was provided [12,16-30]. Risk factors for gastric peritoneal metastases were reported in four studies [15-18]. Survival was also reported in four studies $[12,15,16,28,29]$.

\subsection{Study Characteristics}

Of all included studies, five studies were population-based studies [12,15-18], six studies were observational cohort studies [19-24] and six studies reported surgical cohorts of patients who underwent a staging laparoscopy [25-30]. Study characteristics and outcome measures of all studies are presented in Table 1A,B and Table 2. The five population-based studies were published between 2013 and 2021 [12,15-18]. The number of included patients ranged from 5220 to 34,943 (Table 1A). The six observational cohort studies were published between 2003 and 2015 and the number of included patients ranged from 1108 to 4559 (Table 1B) [19-24]. The six studies that reported the incidence of gastric peritoneal metastases of patients who underwent staging laparoscopy were published between 2013 and 2020, and the number of included patients ranged from 89 to 867 (Table 2) [25-30].

\subsection{Incidence}

\subsubsection{Population-Based Studies}

Incidence of synchronous gastric peritoneal metastases was reported in five populationbased studies from Sweden [17], the United States [18] and the Netherlands [12,15,16]. The proportions of patients presenting with peritoneal metastases from gastric cancer ranged from $10 \%$ to $21 \%$.

\subsubsection{Observational Cohort Studies}

Incidence of synchronous gastric peritoneal metastases was reported in six observational cohort studies from Germany [19], South-Korea [20,22], Japan [21,24], China [21] and the United States [23]. The proportion of patients with gastric peritoneal metastases ranged from $2 \%$ to $15 \%$.

\subsubsection{Surgical Cohort Studies}

Six studies reported the incidence of synchronous gastric peritoneal metastases of patients who underwent a staging laparoscopy. Patient in these studies were eligible for curative intent surgery and no systemic metastases after radiological staging [25-30]. The studies in this subgroup were conducted in the United States [25], China [26,27], Pakistan [28] and the United Kingdom [29,30]. The reported incidence ranged from 13\% to $40 \%$.

\subsection{Risk Factors}

Risk factors for synchronous gastric peritoneal metastases were reported in four studies [15-18]. Younger age [15-17], non-cardia cancer [15-17], female sex [15-17], signet ring cell carcinoma [16,17], diffuse type histology or linitis plastica [15,16], T4 stage [16], Hispanic ethnicity [18] and more than one location of metastases [15] were associated with 
an increased risk of gastric peritoneal metastases. Contradicting results were published regarding the association with positive lymph node status $[15,16]$. Details on risk factors are presented in Table 3.

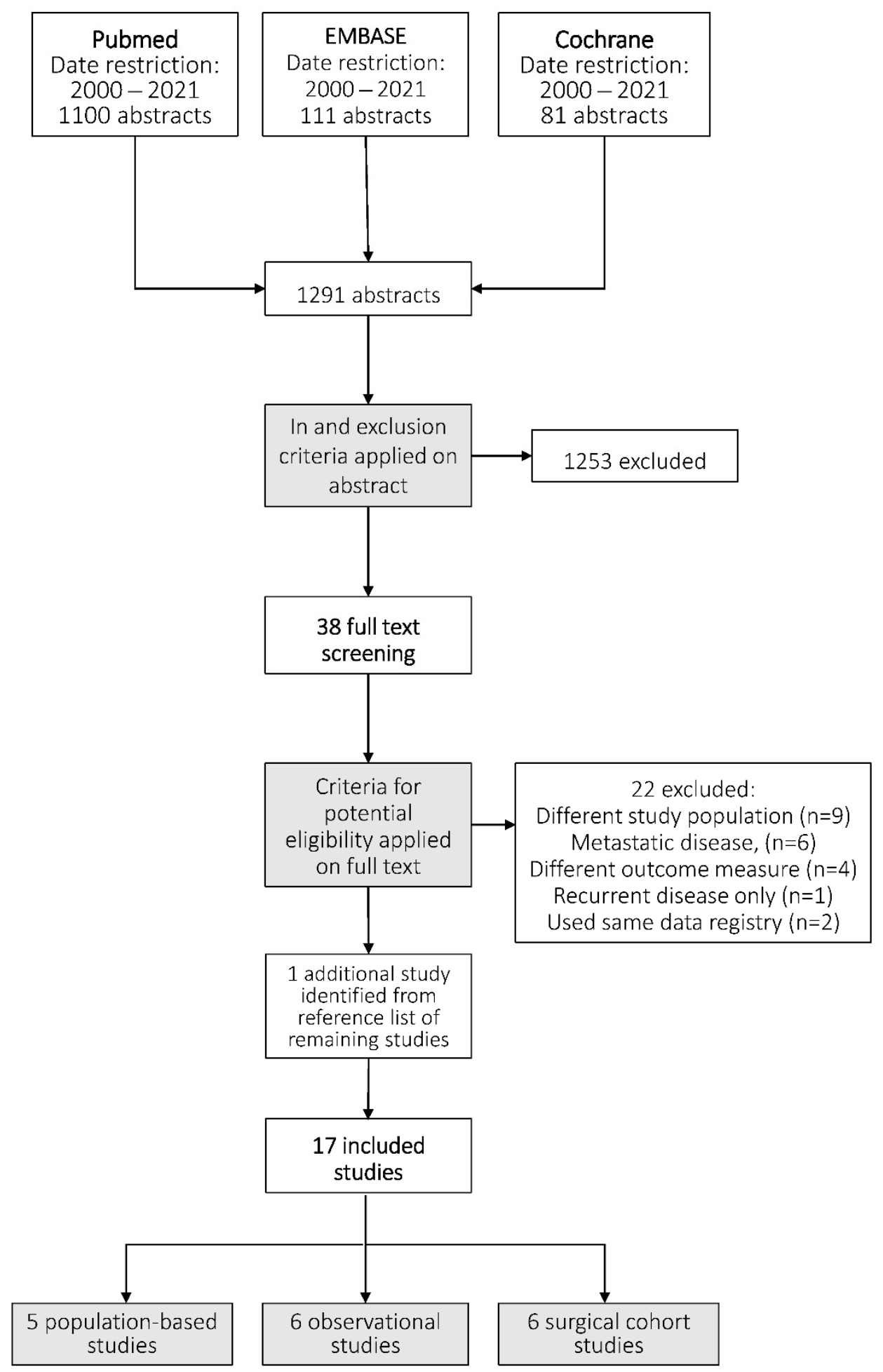

Figure 1. Literature search and study selection. Details of the literature search and study selection are presented in the Appendices A and B, respectively. 
Table 1. Study characteristics of (A) population-based studies and (B) observational cohort studies.

\begin{tabular}{|c|c|c|c|c|c|c|c|c|c|}
\hline \multirow{4}{*}{$\begin{array}{c}\text { First Author } \\
\text { Year }\end{array}$} & \multicolumn{8}{|c|}{ (A) } & \\
\hline & \multicolumn{4}{|c|}{ Design } & \multicolumn{5}{|c|}{ Outcomes } \\
\hline & \multirow[t]{2}{*}{$\begin{array}{l}\text { Enrolment } \\
\text { Period }\end{array}$} & \multirow[t]{2}{*}{ Country } & \multirow[t]{2}{*}{ Setting } & \multirow[t]{2}{*}{ Total Patients (n) } & \multicolumn{4}{|c|}{ Incidence of GPM } & \multirow{2}{*}{$\begin{array}{c}\text { Risk Factors for GPM } \\
\text { Risk factors }\end{array}$} \\
\hline & & & & & Reported & $n$ & $\%$ & Reported & \\
\hline $\begin{array}{c}\text { Koemans }[12]^{\mathrm{a}} \\
2021\end{array}$ & 2008-2017 & $\begin{array}{l}\text { The } \\
\text { Netherlands }\end{array}$ & $\begin{array}{l}\text { Nationwide } \\
\text { register }\end{array}$ & 12,504 & Yes & 2607 & $21 \%$ & No & \\
\hline $\begin{array}{c}\text { Thomassen [16] } \\
2013\end{array}$ & 1995-2012 & $\begin{array}{l}\text { The } \\
\text { Netherlands }\end{array}$ & $\begin{array}{l}\text { Regional } \\
\text { register of } \\
\text { southern part } \\
\text { of the } \\
\text { Netherlands }\end{array}$ & 5220 & Yes & 706 & $14 \%$ & Yes & $\begin{array}{ll}- & \text { Signet ring cell carcinoma } \\
- & \text { Linitis plastica } \\
- & \text { Non-cardia cancer } \\
- & \text { Age }<60 \text { years } \\
- & \text { Female sex } \\
- & \text { T3/T4 stage } \\
- & \text { N1-N3 stage } \\
- & \text { Poor tumour differentiation }\end{array}$ \\
\hline $\begin{array}{l}\text { Riihimäki [17] } \\
2016\end{array}$ & 2002-2012 & Sweden & $\begin{array}{l}\text { Nationwide } \\
\text { register }\end{array}$ & 7559 & Yes & 936 & $12 \%$ & Yes & $\begin{array}{ll}- & \text { Signet ring cell carcinoma } \\
- & \text { Non-cardia cancer } \\
- & \text { Age }<60 \text { years } \\
- & \text { Female sex }\end{array}$ \\
\hline $\begin{array}{c}\text { Choi [18] } \\
2020\end{array}$ & 2004-2014 & United States & $\begin{array}{l}\text { State register } \\
\text { of California }\end{array}$ & 16,275 & Yes & 1691 & $10 \%$ & Yes & - Hispanic ethnicity \\
\hline
\end{tabular}


Table 1. Cont.

(B)

\begin{tabular}{|c|c|c|c|c|c|c|c|}
\hline \multirow[b]{2}{*}{$\begin{array}{c}\text { First Author } \\
\text { Year }\end{array}$} & \multicolumn{4}{|c|}{ Design } & \multicolumn{3}{|c|}{ Outcomes } \\
\hline & $\begin{array}{l}\text { Enrolment } \\
\text { Period }\end{array}$ & Country & Setting & Total Patients $(n)$ & & Incidence of GPM & \\
\hline & & & & & Reported & $\mathrm{n}$ & $\%$ \\
\hline $\begin{array}{l}\text { Seyfried [19] } \\
2015\end{array}$ & 1986-2013 & Germany & Single centre & 1108 & Yes & 158 & $14 \%$ \\
\hline $\begin{array}{c}\text { Park [20] } \\
2010\end{array}$ & 2000-2005 & Korea & Single centre & 3193 & Yes & 104 & $3 \%$ \\
\hline $\begin{array}{c}\mathrm{Yu}[21] \\
2010\end{array}$ & $\begin{array}{l}1993-2006 \\
1980-2003\end{array}$ & JapanChina & Multicentre & $\begin{array}{l}2063 \\
2496\end{array}$ & Yes & $\begin{array}{c}42 \\
324\end{array}$ & $\begin{array}{r}2 \% \\
13 \% \\
\end{array}$ \\
\hline $\begin{array}{l}\text { Kim [22] } \\
2003\end{array}$ & 1988-1998 & Korea & Single centre & 1833 & Yes & 267 & $15 \%$ \\
\hline $\begin{array}{l}\text { Yao [23] } \\
2005\end{array}$ & 1985-1999 & United States & Single centre & 1897 & Yes & 200 & $11 \%$ \\
\hline $\begin{array}{c}\text { Isobe [24] } \\
2013\end{array}$ & 1977-2006 & Japan & Single centre & 3818 & Yes & 447 & $12 \%$ \\
\hline
\end{tabular}

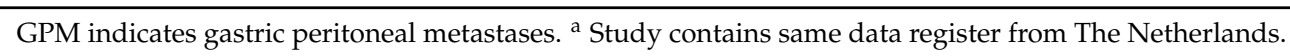


Table 2. Study characteristics of studies on gastric cancer and staging laparoscopy.

\begin{tabular}{|c|c|c|c|c|c|c|c|c|c|}
\hline \multirow{3}{*}{$\begin{array}{l}\text { First Author } \\
\text { Year }\end{array}$} & \multicolumn{6}{|c|}{ Design } & \multicolumn{3}{|c|}{ Outcomes } \\
\hline & \multirow[t]{2}{*}{ Enrolment Period } & \multirow[t]{2}{*}{ Country } & \multirow[t]{2}{*}{ Setting } & & \multirow[t]{2}{*}{ Inclusion Criteria } & \multirow[t]{2}{*}{ Total Patients $(n)$} & \multicolumn{3}{|c|}{ Incidence of GPM } \\
\hline & & & & & & & Reported & $\mathrm{n}$ & $\%$ \\
\hline $\begin{array}{l}\text { Allen [25] } \\
2020\end{array}$ & 1995-2018 & United States & Single centre & $\begin{array}{l}- \\
- \\
-\end{array}$ & $\begin{array}{l}\text { Gastric cancer } \\
\text { Histopathological confirmation } \\
\text { by endoscopic ultrasound } \\
\text { Underwent SL }\end{array}$ & 867 & Yes & 175 & $20 \%$ \\
\hline $\begin{array}{c}\mathrm{Hu}[26] \\
2016\end{array}$ & 2004-2014 & China & Single centre & $\begin{array}{l}- \\
-\end{array}$ & $\begin{array}{l}\text { Advanced stage gastric cancer } \\
\text { Underwent SL }\end{array}$ & 582 & Yes & 118 & $20 \%$ \\
\hline $\begin{array}{l}\text { Yang [27] } \\
2020\end{array}$ & 2014-2019 & China & Single centre & $\begin{array}{l}- \\
- \\
- \\
- \\
-\end{array}$ & $\begin{array}{l}\text { Gastric cancer } \\
\text { Potentially resectable } \\
\text { Histopathological confirmation } \\
\text { M0 on preoperative screening } \\
\text { Underwent SL }\end{array}$ & 672 & Yes & 89 & $13 \%$ \\
\hline $\begin{array}{l}\text { Bhatti [28] } \\
\quad 2014\end{array}$ & 2005-2012 & Pakistan & Single centre & $\begin{array}{l}- \\
- \\
- \\
-\end{array}$ & $\begin{array}{l}\text { Gastric cancer } \\
\text { Potentially resectable } \\
\text { M0 on preoperative screening } \\
\text { Underwent SL }\end{array}$ & 89 & Yes & 36 & $40 \%$ \\
\hline $\begin{array}{l}\text { Convie [29] } \\
\quad 2015\end{array}$ & 2007-2013 & United Kingdom & Single centre & $\begin{array}{l}- \\
- \\
- \\
-\end{array}$ & $\begin{array}{l}\text { Gastric cancer } \\
\text { Potentially resectable } \\
\text { M0 on preoperative screening } \\
\text { Underwent SL }\end{array}$ & 159 & Yes & 36 & $23 \%$ \\
\hline $\begin{array}{l}\text { Munasinghe [30] } \\
2013\end{array}$ & 2006-2010 & United Kingdom & Single centre & $\begin{array}{l}- \\
- \\
-\end{array}$ & $\begin{array}{l}\text { Gastric cancer } \\
\text { Potentially resectable } \\
\text { Underwent SL }\end{array}$ & 142 & Yes & 19 & $13 \%$ \\
\hline
\end{tabular}


Table 3. Risk factors for synchronous gastric peritoneal metastases.

\begin{tabular}{|c|c|c|c|}
\hline Study & Groups & OR & $95 \% \mathrm{CI}$ \\
\hline \multicolumn{4}{|c|}{ Age } \\
\hline \multirow[t]{4}{*}{ Koemans et al. (2020) [15] } & $<45$ years & Ref. & Ref. \\
\hline & $46-60$ years & 0.74 & $0.6-0.9$ \\
\hline & $61-75$ years & 0.62 & $0.5-0.8$ \\
\hline & $>75$ years & 0.52 & $0.4-0.7$ \\
\hline \multirow[t]{4}{*}{ Thomassen et al. (2013) [16] } & $<60$ years & Ref. & Ref. \\
\hline & $60-69$ years & 0.7 & $0.5-0.9$ \\
\hline & 70-79 years & 0.5 & $0.4-0.6$ \\
\hline & $>80$ years & 0.3 & $0.2-0.3$ \\
\hline \multicolumn{4}{|l|}{ Riihimaki et al. (2015) [17] } \\
\hline \multirow[t]{3}{*}{ Single metastasis } & $<60$ years & Ref. & Ref. \\
\hline & 70-79 years & 0.5 & $0.4-0.7$ \\
\hline & $>79$ years & 0.3 & $0.2-0.4$ \\
\hline \multirow[t]{4}{*}{ Multiple metastases } & $<60$ years & Ref. & Ref. \\
\hline & 60-69 years & 0.8 & $0.7-1.0$ \\
\hline & 70-79 years & 0.5 & $0.4-0.6$ \\
\hline & $>79$ years & 0.2 & $0.2-0.3$ \\
\hline Study & Groups & OR & $95 \% \mathrm{CI}$ \\
\hline \multicolumn{4}{|c|}{ Location of primary gastric tumour } \\
\hline \multirow[t]{4}{*}{ Koemans et al. (2020) [15] } & OGJ/cardia & Ref. & Ref. \\
\hline & Proximal/Middle stomach & 2.4 & $2.1-2.8$ \\
\hline & Distal stomach & 2.7 & $2.3-3.1$ \\
\hline & Overlapping location & 3.6 & $3.1-4.1$ \\
\hline \multirow[t]{3}{*}{ Thomassen et al. (2013) [16] } & Non-cardia & Ref. & Ref. \\
\hline & Cardia & 0.4 & $0.3-0.5$ \\
\hline & Overlapping lesions/NOS & 1.3 & $1.0-1.6$ \\
\hline \multicolumn{4}{|l|}{ Riihimaki et al. (2015) [17] } \\
\hline \multirow[t]{3}{*}{ Single metastasis } & Cardia & Ref. & Ref. \\
\hline & Fundus/Corpus & 1.7 & $1.3-2.2$ \\
\hline & Antrum/Pylorus & 1.8 & $1.3-2.3$ \\
\hline \multirow[t]{3}{*}{ Multiple metastases } & Cardia & Ref. & Ref. \\
\hline & Fundus/Corpus & 1.8 & $1.4-2.2$ \\
\hline & Antrum/Pylorus & 1.6 & $1.2-2.0$ \\
\hline \multicolumn{4}{|c|}{ Sex } \\
\hline \multirow[t]{2}{*}{ Koemans et al. (2020) [15] } & Male & Ref. & Ref. \\
\hline & Female & 1.5 & $1.3-1.6$ \\
\hline \multirow[t]{2}{*}{ Thomassen et al. (2013) [16] } & Male & Ref. & Ref. \\
\hline & Female & 1.2 & $1.0-1.5$ \\
\hline \multicolumn{4}{|l|}{ Riihimaki et al. (2015) [17] } \\
\hline \multirow[t]{2}{*}{ Single metastasis } & Male & Ref. & Ref. \\
\hline & Female & 1.1 & $1.0-1.4$ \\
\hline \multirow[t]{2}{*}{ Multiple metastases } & Male & Ref. & Ref. \\
\hline & Female & 1.3 & $1.1-1.5$ \\
\hline \multirow{4}{*}{ Koemans et al. (2020) [15] } & Histology & & \\
\hline & Intestinal type & Ref. & Ref. \\
\hline & Diffuse type & 2.8 & $2.5-3.1$ \\
\hline & Mixed type & 2.1 & $1.7-2.7$ \\
\hline \multirow[t]{3}{*}{ Thomassen et al. (2013) [16] } & Adenocarcinoma & Ref. & Ref. \\
\hline & Signet ring cell carcinoma & 1.7 & $1.4-2.2$ \\
\hline & Linitis plastica & 2.0 & $1.5-2.8$ \\
\hline
\end{tabular}


Table 3. Cont.

\begin{tabular}{cccc}
\hline Study & Groups & OR & 95\% CI \\
\hline Riihimaki et al. (2015) [17] & Adenocarcinoma & Ref. & Ref. \\
Single metastases & Signet ring cell carcinoma & 2.5 & $2.0-3.1$ \\
\hline Multiple metastases & Adenocarcinoma & Ref. & Ref. \\
& Signet ring cell carcinoma & 2.3 & $1.9-2.7$ \\
\hline Study & Groups & OR & 95\% CI \\
\hline Koemans et al. (2020) [15] & T stage & & \\
& T1 & Ref. & Ref. \\
& T2-3 & 2.1 & $1.3-3.2$ \\
\hline Thomassen et al. (2013) [16] & T4 & 3.0 & $1.9-4.7$ \\
\hline T1-2 & Ref. & Ref. \\
& T3 & 2.4 & $1.7-3.3$ \\
& T4 & 2.9 & $2.1-4.0$ \\
\hline Koemans et al. (2020) [15] & N stage & & \\
& N0 & Ref. & Ref. \\
& N1-2 & 0.4 & $0.3-0.4$ \\
& N3 & 0.3 & $0.2-0.3$ \\
\hline Thomassen et al. (2013) [16] & N0 & Ref. & Ref. \\
& N+ & 4.0 & $2.2-7.3$ \\
\hline
\end{tabular}

\begin{tabular}{cccc}
\hline Choi et al. (2020) [18] & & & \\
Non-Hispanic white vs. Hispanic & Non-Hispanic white & Ref. & Ref. \\
& Hispanic & 1.9 & $1.6-2.1$ \\
\hline Asian/other vs. Hispanic & Asian/other & Ref. & Ref. \\
& Hispanic & 1.5 & $1.3-1.7$ \\
\hline & Number of metastatic locations & \\
\hline Koemans et al. (2020) [15] & 1 metastasis & Ref. & Ref. \\
& $>1$ metastases & 1.6 & $1.5-1.8$
\end{tabular}

Non-significant risk factors were excluded. OR indicates odds ratio. CI indicates confidence interval. Ref. indicates the reference category.

\subsection{Survival}

Survival was reported in three population-based studies and in one surgical cohort study $[12,15,16,29]$. One study reported a median overall survival (OS) of 4.0 months in patients with gastric peritoneal metastases [16]. Another study reported survival of gastric peritoneal metastases by histological subtype with a median OS of 4.6 months for diffuse type gastric cancer versus 5.1 months for intestinal type gastric cancer with peritoneal metastases [15]. Furthermore, a study on gastric peritoneal metastases reported a median OS of 2.1 months in patients who did not receive systemic therapy versus 9.4 months in patients who received systemic therapy [12]. A study documented a median OS of 7 months in a gastric cancer patients cohort that underwent staging laparoscopy [29].

\section{Discussion}

In this systematic review, the proportion of patients with synchronous peritoneal metastases from gastric cancer origin ranged from $10-21 \%$ in population-based studies [12,16-18], from $2-15 \%$ in observational cohort studies [19-24] and from $13-40 \%$ in surgical cohort studies [25-30]. Interestingly, the highest incidence of synchronous peritoneal metastases $(21 \%)$ was reported in the most recent population-based study [12]. This may be attributable to the improvement of imaging techniques resulting in a higher detection rate of the typically small peritoneal lesions as well as a higher awareness towards peritoneal 
metastases amongst radiologists. Moreover, the introduction of a standard diagnostic laparoscopy in the staging guidelines of operable patients with resectable gastric cancer will have contributed to the increased documentation of peritoneal metastases. Identified risk factors for gastric peritoneal metastases were younger age, non-cardia cancer, female sex, signet ring cell carcinoma, diffuse type histology or linitis plastica, T4 stage and Hispanic ethnicity [15-18]. Median OS in patients with gastric peritoneal metastases ranged from 2 to 9 months $[12,15,16,29]$.

To the best of our knowledge, this is the first comprehensive systematic review providing an overview on incidence, risk factors and survival for synchronous gastric peritoneal metastases. Previous studies have performed a systematic review on gastric cancer in general but reported very limited information about peritoneal metastases with none of these studies focusing specifically on the incidence of synchronous peritoneal metastases [31,32]. From these studies, it can be concluded that the proportion of patients presenting with metastases at any location increased over time from $24 \%$ in 1990 to $44 \%$ in 2011 . The peritoneum is recognized as one of the most common metastatic sites in gastric cancer patients, ranking second after the liver $[3,17]$. Again, improved radiologic and staging techniques probably explain the stage migration towards more patients with metastatic disease. One review on gastric cancer confirmed the striking difference of a much higher incidence of gastric cancer in Asian countries than in Western countries, as well as a less advanced stage at the time of diagnosis [33]. The latter may be explained by the mass screening programs for gastric cancer in high-incidence regions such as Japan and Korea, aiming to diagnose the cancer at an early stage [34].

In the current review, several risk factors to develop peritoneal metastases were identified, among which are a younger age. Interestingly, a meta-analysis on young patients with gastric cancer also reported that these patients were more often females with diffuse gastric cancer and signet ring cell carcinoma and were more often diagnosed with peritoneal metastases [35]. Therefore, young patients may have a poorer tumour biology and subsequently may be more at risk for peritoneal metastases. On the other hand, younger patients are usually in a good condition and are thus more likely to receive a thorough diagnostic work-up which increases the chance of discovering peritoneal metastases. Therefore, it remains unknown whether the higher incidence of peritoneal metastases in younger patients reflects a more aggressive tumour biology or whether this finding is biased by an intensified diagnostic workup.

Other risk factors, such as a T4 stage and signet ring cell differentiation, were previously identified to be associated with an increased incidence of peritoneal metastases from colorectal cancer [36]. Furthermore, linitis plastica, tumour-positive lymph nodes and a primary tumour not located in the cardia were previously reported as risk factors for metastases in gastric cancer patients [37]. This highlights the role of a more advanced tumour stage in the development of peritoneal metastases. Remarkably, in one study, tumour-positive lymph nodes were associated with a higher rate of systemic metastases but with a lower risk of peritoneal metastases [15]. At first, this may seem contradictory, but this can be explained by the fact that this study was performed in patients presenting with metastatic disease only. Patients with lymph node involvement and systemic metastases on computed tomography (CT) probably have not undergone a staging laparoscopy since they are already considered to have unresectable disease. As a result, peritoneal metastases may have been missed in many patients as they are usually hard to diagnose by radiologic imaging alone.

Staging laparoscopy is frequently carried out in patients with (advanced) gastric cancer eligible for curative intent surgery and without metastases after radiology staging. In this systematic review, studies on patients who underwent staging laparoscopy generally reported a higher incidence of gastric peritoneal metastases compared to the other studies, up to $40 \%$. This proportion is comparable to the numbers of a recent review specifically on gastric cancer patients undergoing staging laparoscopy [38]. This emphasizes the importance of a staging laparoscopy in patients with gastric cancer. Less invasive diagnostic 
modalities, such as (positron emission tomography) CT and magnetic resonance imaging, need to be further improved to increase their accuracy for diagnosing peritoneal metastases.

As shown in this review, survival of gastric peritoneal metastases is poor, ranging from 2 to 9 months, depending on systemic therapy or histological subtype. Similar poor survival outcomes for patients receiving best supportive care, or systemic therapy only, were previously reported for peritoneal metastases of other primary tumours, such as colorectal and pancreatic cancer, which emphasizes the need for new treatment options for patients with peritoneal metastases, regardless of the origin of the tumour [39-41]. In gastric cancer with peritoneal metastases, experimental treatment options such as CRSHIPEC or PIPAC are currently being investigated $[8,10]$. Although limited literature is available about this experimental treatment, preliminary results seem promising [6,7,42] Furthermore, it needs to be investigated whether patients with peritoneal metastases may also benefit from new systemic treatment strategies such as docetaxel-based triplet FLOT therapy (fluorouracil plus leucovorin, oxaliplatin and docetaxel) that has been shown to improve survival in patients with locally advanced resectable gastric cancer [43].

This review has several limitations. Firstly, some population-based studies used the same data registries which results in overlapping use of patient characteristics [12,15]. However, these studies reported on different outcomes and therefore did not result in duplication of data. Secondly, the population-based studies were performed in western countries, whereas the observational cohort studies were mostly performed in Asian countries. The prevalence of gastric cancer in western countries is low compared to the prevalence in Asian countries, and types of histology vary among these different parts of the world where diffuse type is more common in Asian countries [1,2,43-45]. The observational cohort studies revealed large heterogeneity within and across these studies. This may lead to an incomplete overview of patients diagnosed with synchronous gastric peritoneal metastases in non-western countries. Finally, this systematic review focused on synchronous peritoneal metastases only, whereas it is known that metachronous peritoneal metastases frequently occur after curative treatment for gastric cancer. Recent literature showed that the peritoneum $(36 \%)$ was the most common initial site of recurrence after potentially curative gastric cancer surgery [46]. Population-based studies with adequate follow-up to include metachronous peritoneal metastases are therefore designated to provide a more accurate overview of the total burden of peritoneal metastases from gastric cancer.

To conclude, in this systematic review, synchronous peritoneal metastases were frequently commonly diagnosed in patients with gastric cancer with an incidence up to $21 \%$ in most recent population-based studies. Furthermore, prognosis of patients with gastric peritoneal metastases is poor. Given the high incidence and poor prognosis, this patient category is an important focus for future research on diagnostic features and effective treatment options to improve survival.

Author Contributions: Conceptualization, A.R., R.J.L. and I.H.J.T.d.H.; methodology, A.R., R.J.L., F.N.v.E. and I.H.J.T.d.H.; validation, A.R., R.J.L., M.D.P.L., G.A.P.N., F.N.v.E., J.W.v.S. and I.H.J.T.d.H.; formal analysis, A.R., R.J.L., M.D.P.L., G.A.P.N., F.N.v.E., J.W.v.S. and I.H.J.T.d.H.; resources, A.R., R.J.L., M.D.P.L., G.A.P.N., F.N.v.E., J.W.v.S. and I.H.J.T.d.H.; writing-original draft preparation, A.R., R.J.L., M.D.P.L., G.A.P.N., F.N.v.E., J.W.v.S. and I.H.J.T.d.H.; writing-review and editing, A.R., R.J.L., M.D.P.L., G.A.P.N., F.N.v.E., J.W.v.S. and I.H.J.T.d.H.; supervision, M.D.P.L., G.A.P.N., F.N.v.E., J.W.v.S. and I.H.J.T.d.H. All authors have read and agreed to the published version of the manuscript.

Funding: This research received no external funding.

Institutional Review Board Statement: Not applicable.

Informed Consent Statement: Not applicable.

Data Availability Statement: Not applicable. 
Conflicts of Interest: De Hingh reports an unrestricted research grant from RanD/QPS and Roche, outside the submitted work, paid to the institute. Nieuwenhuijzen and Luyer report consultancy payments from Medtronic outside the submitted work, paid to the institute. The other authors have no conflict of interest to declare.

\section{Appendix A. Search Strategies}

PubMed search strategy

Date of search: 15 August 2021

Search query: $((((($ Peritoneal Neoplasms[MeSH Terms]) OR (peritoneal metastases OR peritoneal metastasis OR peritoneal carcinomatosis OR peritoneal dissemination OR peritoneal spread OR peritoneal disease OR peritoneal tumour OR peritoneal tumor))) AND (((gastric neoplasms[MeSH Terms]) OR (gastric cancer OR gastric malignancy OR gastric neoplasm OR stomach cancer OR stomach malignancy OR stomach neoplasm OR gastric carcinoma $)))$ AND ((((incidence[MeSH Terms]) OR (incidence)) OR ((prevalence[MeSH Terms]) OR (prevalence))) OR ((risk factors[MeSH Terms]) OR (risk factors)))) NOT ((case report) OR (review))

Publication date restriction: 2000-2021

Items found: 1100

EMBASE search strategy

Date of search: 15 August 2021

Search query: ('incidence':ab,ti OR 'prevalence':ab,ti OR 'risk factors':ab,ti) AND ('peritoneum metastasis': ab,ti OR 'peritoneum tumor':ab,ti OR 'peritoneal disease':ab,ti OR 'carcinomatous peritonitis':ab,ti OR 'peritoneal disease' /exp/mj) AND ('stomach cancer':ab,ti OR 'stomach carcinoma':ab,ti OR 'stomach cancer' / exp/mj)

Publication date restriction: 2000-2021

Items found: 111

Cochrane search strategy

Date of search: 15 August 2021

Search query: Gastric peritoneal metastases

Publication date restriction: 2000-2021

Items found: 81

\section{Appendix B. Reasons for Exclusion of Potentially Eligible Studies after Full Text Screening}

Different study population $(n=9)$

1. Ji, L.; Selleck, M.J.; Morgan, J.W.; Xu, J.; Babcock, B.D.; Shavlik, D.; Wall, N.R.; Langridge, W.H.; Lum, S.S.; Garberoglio, C.A.; et al. Gastric Cancer Peritoneal Carcinomatosis Risk Score. Ann. Surg. Oncol. 2020, 27,240-247.

2. Yook, J.H.; Oh, S.T.; Kim, B.S. Clinicopathological analysis of Borrmann type IV gastric cancer. Cancer Res. Treat. 2005, 37, 87-91.

3. Fanotto, V.; Fornaro, L.; Bordonaro, R.; Rosati, G.; Rimassa, L.; Di Donato, S.; Santini, D.; Tomasello, G.; Leone, F.; Silvestris, N.; et al. Second-line treatment efficacy and toxicity in older vs. non-older patients with advanced gastric cancer: A multicentre real-world study. J. Geriatr. Oncol. 2019, 10, 591-597.

4. Solon, J.G.; O’Neill, M.; Chang, K.H.; Deady, S.; Cahill, R.; Moran, B.; Shields, C.; Mulsow, J. An 18 year population-based study on site of origin and outcome of patients with peritoneal malignancy in Ireland. Eur. J. Surg. Oncol. 2017, 43,1924-1931. 
5. Koo, D.H.; Ryu, M.H.; Ryoo, B.Y.; Seo, J.; Lee, M.Y.; Chang, H.M.; Lee, J.L.; Lee, S.S.; Kim, T.W.; Kang, Y.K. Improving trends in survival of patients who receive chemotherapy for metastatic or recurrent gastric cancer: 12 years of experience at a single institution. Gastric Cancer 2015, 18, 346-353.

6. Sarela, A.I.; Yelluri, S. Leeds Upper Gastrointestinal Cancer Multidisciplinary Team. Gastric adenocarcinoma with distant metastasis: is gastrectomy necessary? Arch. Surg. 2007, 142, 143-149; discussion 149.

7. Dhobi, M.A.; Wani, K.A.; Parray, F.Q.; Wani, R.A.; Wani, M.L.; Peer, G.Q.; Abdullah, S.; Wani, I.A.; Wani, M.A.; Shah, M.A.; et al. Gastric cancer in young patients. Int. J. Surg. Oncol. 2013, 2013, 981654.

8. Sarela, A.I.; Miner, T.J.; Karpeh, M.S.; Coit, D.G.; Jaques, D.P.; Brennan, M.F. Clinical outcomes with laparoscopic stage M1, unresected gastric adenocarcinoma. Ann. Surg. 2006, 243, 189-195.

9. Ahmed, A.; Ukwenya, A.Y.; Makama, J.G.; Mohammad, I. Management and outcome of gastric carcinoma in Zaria, Nigeria. Afr. Health Sci. 2011, 11, 353-361.

Metastatic disease $(n=6)$

1. Korivi, B.R.; Faria, S.; Aly, A.; Sun, J.; Patnana, M.; Jensen, C.T.; Wagner-Bartak, N.; Bhosale, P.R. Intestinal and diffuse gastric cancer: a retrospective study comparing primary sites. Clin. Imaging 2019, 56, 33-40, doi:10.1016/j.clinimag.2019.03.002.

2. Tan, H.L.; Chia, C.S.; Tan, G.H.C.; Choo, S.P.; Tai, D.W.; Chua, C.W.L.; Ng, M.C.H.; Soo, K.C.; Teo, M.C.C. Metastatic gastric cancer: Does the site of metastasis make a difference? Asia Pac. J. Clin. Oncol. 2019, 15, 10-17.

3. Carmona-Bayonas, A.; Jiménez-Fonseca, P.; Echavarria, I.; Sánchez Cánovas, M.; Aguado, G.; Gallego, J.; Custodio, A.; Hernández, R.; Viudez, A.; Cano, J.M.; et al. AGAMENON Study Group. Surgery for metastases for esophageal-gastric cancer in the real world: Data from the AGAMENON national registry. Eur. J. Surg. Oncol. 2018, 44, 1191-1198.

4. Chen, S.; Li, Y.F.; Feng, X.Y.; Zhou, Z.W.; Yuan, X.H.; Chen, Y.B. Significance of palliative gastrectomy for late-stage gastric cancer patients. J. Surg. Oncol. 2012, 106, 862-871.

5. Shridhar, R.; Almhanna, K.; Hoffe, S.E.; Fulp, W.; Weber, J.; Chuong, M.D.; Meredith, K.L. Increased survival associated with surgery and radiation therapy in metastatic gastric cancer: A Surveillance, Epidemiology, and End Results database analysis. Cancer 2013, 119, 1636-1642.

6. Kim, D.Y.; Kim, H.R.; Kim, Y.J.; Kim, S. Clinicopathological features of patients with Borrmann type IV gastric carcinoma. ANZ J. Surg. 2002, 72, 739-742.

Measure $(n=4)$

1. Rona, K.A.; Schwameis, K.; Zehetner, J.; Samakar, K.; Green, K.; Samaan, J.; Sandhu, K.; Bildzukewicz, N.; Katkhouda, N.; Lipham, J.C. Gastric cancer in the young: An advanced disease with poor prognostic features. J. Surg. Oncol. 2017, 115, 371-375.

2. Kim, S.H.; Choi, Y.H.; Kim, J.W.; Oh, S.; Lee, S.; Kim, B.G.; Lee, K.L. Clinical significance of computed tomography-detected ascites in gastric cancer patients with peritoneal metastases. Medicine 2018, 97, e9343.

3. Kim, D.Y.; Joo, J.K.; Ryu, S.Y.; Park, Y.K.; Kim, Y.J.; Kim, S.K. Clinicopathologic characteristics of gastric carcinoma in elderly patients: a comparison with young patients. World J. Gastroenterol. 2005, 11, 22-26, doi:10.3748/wjg.v11.i1.22.

4. Nakamura, R.; Saikawa, Y.; Takahashi, T.; Takeuchi, H.; Asanuma, H.; Yamada, Y.; Kitagawa, Y. Retrospective analysis of prognostic outcome of gastric cancer in young patients. Int. J. Clin Oncol. 2011, 16, 328-334.

Recurrent disease only $(n=1)$

1. Kong, J.H.; Lee, J.; Yi, C.A.; Park, S.H.; Park, J.O.; Park, Y.S.; Lim, H.Y.; Park, K.W.; Kang, W.K. Lung metastases in metastatic gastric cancer: pattern of lung metastases and clinical outcome. Gastric Cancer 2012, 15, 292-298. 
Used same data registry $(n=2)$

1. Thomassen, I.; Bernards, N.; van Gestel, Y.R.; Creemers, G.J.; Jacobs, E.M.; Lemmens, V.E.; de Hingh, I.H. Chemotherapy as palliative treatment for peritoneal carcinomatosis of gastric origin. Acta Oncol. 2014, 53, 429-432.

2. Allen, C.J.; Newhook, T.E.; Vreeland, T.J.; Das, P.; Minsky, B.D.; Blum, M.; Song, S.; Ajani, J.; Ikoma, N.; Mansfield, P.F.; et al. Yield of peritoneal cytology in staging patients with gastric and gastroesophageal cancer. J. Surg. Oncol. 2019, 120, 1350-1357.

\section{References}

1. World Health Organisation. Global Cancer Observatory. Available online: https://gco.iarc.fr/today/online-analysis-multi-bars (accessed on 26 June 2021).

2. Sung, H.; Ferlay, J.; Siegel, R.L.; Laversanne, M.; Soerjomataram, I.; Jemal, A.; Bray, F. Global Cancer Statistics 2020: GLOBOCAN Estimates of Incidence and Mortality Worldwide for 36 Cancers in 185 Countries. CA Cancer J. Clin. 2021, 71, 209-249. [CrossRef]

3. Bernards, N.; Creemers, G.J.; Nieuwenhuijzen, G.A.; Bosscha, K.; Pruijt, J.F.; Lemmens, V.E. No improvement in median survival for patients with metastatic gastric cancer despite increased use of chemotherapy. Ann. Oncol. 2013, 24, 3056-3060. [CrossRef]

4. van Driel, W.J.; Koole, S.N.; Sikorska, K.; Schagen van Leeuwen, J.H.; Schreuder, H.W.R.; Hermans, R.H.M.; de Hingh, I.H.J.T.; van der Velden, J.; Arts, H.J.; Massuger, L.F.A.G.; et al. Hyperthermic Intraperitoneal Chemotherapy in Ovarian Cancer. N. Engl. J. Med. 2018, 378, 230-240. [CrossRef]

5. Verwaal, V.J.; Bruin, S.; Boot, H.; van Slooten, G.; van Tinteren, H. 8-year follow-up of randomized trial: Cytoreduction and hyperthermic intraperitoneal chemotherapy versus systemic chemotherapy in patients with peritoneal carcinomatosis of colorectal cancer. Ann. Surg. Oncol. 2008, 15, 2426-2432. [CrossRef]

6. Yang, X.J.; Huang, C.Q.; Suo, T.; Mei, L.J.; Yang, G.L.; Cheng, F.L.; Zhou, Y.-F.; Xiong, B.; Yonemura, Y.; Li, Y. Cytoreductive surgery and hyperthermic intraperitoneal chemotherapy improves survival of patients with peritoneal carcinomatosis from gastric cancer: Final results of a phase III randomized clinical trial. Ann. Surg Oncol. 2011, 18, 1575-1581. [CrossRef]

7. Bonnot, P.E.; Piessen, G.; Kepenekian, V.; Decullier, E.; Pocard, M.; Meunier, B.; Bereder, J.-M.; Abboud, K.; Marchal, F.; Quenet, F.; et al. Cytoreductive Surgery With or Without Hyperthermic Intraperitoneal Chemotherapy for Gastric Cancer With Peritoneal Metastases (CYTO-CHIP study): A Propensity Score Analysis. J. Clin. Oncol. 2019, 37, 2028-2040. [CrossRef]

8. Koemans, W.J.; van der Kaaij, R.T.; Boot, H.; Buffart, T.; Veenhof, A.; Hartemink, K.J.; Grootscholten, C.; Snaebjornsson, P.; Retel, V.P.; Van Tinteren, H.; et al. Cytoreductive surgery and hyperthermic intraperitoneal chemotherapy versus palliative systemic chemotherapy in stomach cancer patients with peritoneal dissemination, the study protocol of a multicentre randomised controlled trial (PERISCOPE II). BMC Cancer 2019, 19, 420. [CrossRef]

9. Rudloff, U.; Langan, R.C.; Mullinax, J.E.; Beane, J.D.; Steinberg, S.M.; Beresnev, T.; Rn, C.C.W.; Rn, M.W.; Rn, M.A.T.; Schrump, D.; et al. Impact of maximal cytoreductive surgery plus regional heated intraperitoneal chemotherapy (HIPEC) on outcome of patients with peritoneal carcinomatosis of gastric origin: Results of the GYMSSA trial. J. Surg. Oncol. 2014, 110, 275-284. [CrossRef]

10. Alyami, M.; Bonnot, P.E.; Mercier, F.; Laplace, N.; Villeneuve, L.; Passot, G.; Bakrin, N.; Kepenekian, V.; Glehen, O. Pressurized intraperitoneal aerosol chemotherapy (PIPAC) for unresectable peritoneal metastasis from gastric cancer. Eur. J. Surg. Oncol. 2021, 47, 123-127. [CrossRef]

11. Ishigami, H.; Fujiwara, Y.; Fukushima, R.; Nashimoto, A.; Yabusaki, H.; Imano, M.; Imamoto, H.; Kodera, Y.; Uenosono, Y.; Amagai, K.; et al. Phase III Trial Comparing Intraperitoneal and Intravenous Paclitaxel Plus S-1 versus Cisplatin Plus S-1 in Patients With Gastric Cancer With Peritoneal Metastasis: PHOENIX-GC Trial. J. Clin. Oncol. 2018, 36, 1922-1929. [CrossRef]

12. Koemans, W.J.; Lurvink, R.J.; Grootscholten, C.; Verhoeven, R.H.A.; de Hingh, I.H.; van Sandick, J.W. Synchronous peritoneal metastases of gastric cancer origin: Incidence, treatment and survival of a nationwide Dutch cohort. Gastric Cancer 2021, 24, 800-809. [CrossRef]

13. Bang, Y.J.; Van Cutsem, E.; Feyereislova, A.; Chung, H.C.; Shen, L.; Sawaki, A.; Lordick, F.; Ohtsu, A.; Omuro, Y.; Satoh, T.; et al. Trastuzumab in combination with chemotherapy versus chemotherapy alone for treatment of HER2-positive advanced gastric or gastro-oesophageal junction cancer (ToGA): A phase 3, open-label, randomised controlled trial. Lancet 2010, 376, 687-697. [CrossRef]

14. Moher, D.; Liberati, A.; Tetzlaff, J.; Altman, D.G. Preferred reporting items for systematic reviews and meta-analyses: The PRISMA statement. J. Clin. Epidemiol. 2009, 62, 1006-1012. [CrossRef]

15. Koemans, W.J.; Luijten, J.; van der Kaaij, R.T.; Grootscholten, C.; Snaebjornsson, P.; Verhoeven, R.H.A.; van Sandick, J. The metastatic pattern of intestinal and diffuse type gastric carcinoma-A Dutch national cohort study. Cancer Epidemiol. 2020, 69, 101846. [CrossRef]

16. Thomassen, I.; van Gestel, Y.R.; van Ramshorst, B.; Luyer, M.D.; Bosscha, K.; Nienhuijs, S.W.; Lemmens, V.E.; de Hingh, I.H. Peritoneal carcinomatosis of gastric origin: A population-based study on incidence, survival and risk factors. Int. J. Cancer 2014, 134, 622-628. [CrossRef]

17. Riihimaki, M.; Hemminki, A.; Sundquist, K.; Sundquist, J.; Hemminki, K. Metastatic spread in patients with gastric cancer. Oncotarget 2016, 7, 52307-52316. [CrossRef] 
18. Choi, A.H.; Ji, L.; Babcock, B.; Ramos, V.; Kwong, M.L.M.; Morgan, J.W.; Do, M.J.S.; Langridge, W.H.R.; DeLeon, M.; Wall, N.R.; et al. Peritoneal carcinomatosis in gastric cancer: Are Hispanics at higher risk? J. Surg. Oncol. 2020, 122, 1624-1629. [CrossRef]

19. Seyfried, F.; Von Rahden, B.H.; Miras, A.D.; Gasser, M.; Maeder, U.; Kunzmann, V.; Germer, C.-T.; Pelz, J.O.; Kerscher, A.G. Incidence, time course and independent risk factors for metachronous peritoneal carcinomatosis of gastric origin-A longitudinal experience from a prospectively collected database of 1108 patients. BMC Cancer 2015, 15, 73. [CrossRef]

20. Park, J.C.; Lee, Y.C.; Kim, J.-H.; Kim, Y.J.; Kil Lee, S.; Shin, S.K.; Hyung, W.J.; Noh, S.H.; Kim, C.B. Clinicopathological features and prognostic factors of proximal gastric carcinoma in a population with high Helicobacter pylori prevalence: A single-center, large-volume study in Korea. Ann. Surg Oncol. 2010, 17, 829-837. [CrossRef]

21. Yu, M.; Zheng, H.-C.; Xia, P.; Takahashi, H.; Masuda, S.; Takano, Y.; Xu, H.-M. Comparison in pathological behaviours \& prognosis of gastric cancers from general hospitals between China \& Japan. Indian J. Med. Res. 2010, 132, $295-302$.

22. Kim, D.Y.; Ryu, S.Y.; Kim, Y.J.; Kim, S.K. Clinicopathological characteristics of gastric carcinoma in young patients. Langenbeck's Arch. Surg. 2003, 388, 245-249. [CrossRef]

23. Yao, J.C.; Tseng, J.F.; Worah, S.; Hess, K.R.; Mansfield, P.F.; Crane, C.H.; Schnirer, I.I.; Reddy, S.; Chiang, S.S.; Najam, A.; et al Clinicopathologic behavior of gastric adenocarcinoma in Hispanic patients: Analysis of a single institution's experience over 15 years. J. Clin. Oncol. 2005, 23, 3094-3103. [CrossRef]

24. Isobe, T.; Hashimoto, K.; Kizaki, J.; Miyagi, M.; Aoyagi, K.; Koufuji, K.; Shirouzu, K. Characteristics and prognosis of gastric cancer in young patients. Oncol. Rep. 2013, 30, 43-49. [CrossRef]

25. Allen, C.J.; Blumenthaler, A.N.; Das, P.; Minsky, B.D.; Blum, M.; Roy-Chowdhuri, S.; Ajani, J.A.; Ikoma, N.; Mansfield, P.F.; Badgwell, B.D. Staging laparoscopy and peritoneal cytology in patients with early stage gastric adenocarcinoma. World J. Surg. Oncol. 2020, 18, 39. [CrossRef]

26. Hu, Y.F.; Deng, Z.W.; Liu, H.; Mou, T.Y.; Chen, T.; Lu, X.; Wang, D.; Yu, J.; Li, G.-X. Staging laparoscopy improves treatment decision-making for advanced gastric cancer. World J. Gastroenterol. 2016, 22, 1859-1868. [CrossRef]

27. Yang, C.; Yang, Y.; Huang, X.; Li, H.; Cheng, H.; Tong, S.; Zheng, Y. A Nomogram Based on Clinicopathologic Features and Preoperative Hematology Parameters to Predict Occult Peritoneal Metastasis of Gastric Cancer: A Single-Center Retrospective Study. Dis. Markers 2020, 2020, 1418978. [CrossRef]

28. Bhatti, A.B.; Haider, S.; Khattak, S.; Syed, A.A. Staging laparoscopy in gastroesophageal and gastric adenocarcinoma: First experience from Pakistan. Indian J. Cancer 2014, 51, 15-17. [CrossRef]

29. Convie, L.; Thompson, R.J.; Kennedy, R.; Clements, W.D.B.; Carey, P.D.; Kennedy, J.A. The current role of staging laparoscopy in oesophagogastric cancer. Ann. R. Coll. Surg. Engl. 2015, 97, 146-150. [CrossRef]

30. Munasinghe, A.; Kazi, W.; Taniere, P.; Hallissey, M.T.; Alderson, D.; Tucker, O. The incremental benefit of two quadrant lavage for peritoneal cytology at staging laparoscopy for oesophagogastric adenocarcinoma. Surg. Endosc. 2013, 27, 4049-4053. [CrossRef]

31. Coccolini, F.; Gheza, F.; Lotti, M.; Virzi, S.; Iusco, D.; Ghermandi, C.; Melotti, R.; Baiocchi, G.; Giulini, S.M.; Ansaloni, L.; et al. Peritoneal carcinomatosis. World J. Gastroenterol. 2013, 19, 979-994. [CrossRef]

32. Ang, T.L.; Fock, K.M. Clinical epidemiology of gastric cancer. Singap. Med. J. 2014, 55, 621-628. [CrossRef]

33. Dicken, B.J.; Bigam, D.L.; Cass, C.; Mackey, J.R.; Joy, A.A.; Hamilton, S.M. Gastric adenocarcinoma: Review and considerations for future directions. Ann. Surg. 2005, 241, 27-39. [CrossRef]

34. Sugano, K. Screening of gastric cancer in Asia. Best Pract. Res. Clin. Gastroenterol. 2015, 29, 895-905. [CrossRef]

35. Kong, X.; Wang, J.L.; Chen, H.M.; Fang, J.Y. Comparison of the clinicopathological characteristics of young and elderly patients with gastric carcinoma: A meta analysis. J. Surg. Oncol. 2012, 106, 346-352. [CrossRef]

36. Lurvink, R.J.; Bakkers, C.; Rijken, A.; van Erning, F.N.; Nienhuijs, S.W.; Burger, J.W.; Creemers, G.; Verhoef, C.; Lemmens, V.; De Hingh, I. Increase in the incidence of synchronous and metachronous peritoneal metastases in patients with colorectal cancer: A nationwide study. Eur. J. Surg. Oncol. 2021, 47, 1026-1033. [CrossRef]

37. Chen, L.; Wang, Y.H.; Cheng, Y.Q.; Du, M.Z.; Shi, J.; Fan, X.S.; Zhou, X.L.; Zhang, Y.F.; Guo, L.C.; Xu, G.F.; et al. Risk factors of lymph node metastasis in 1620 early gastric carcinoma radical resections in Jiangsu Province in China: A multicenter clinicopathological study. J. Dig. Dis. 2017, 18, 556-565. [CrossRef]

38. Fukagawa, T. Role of staging laparoscopy for gastric cancer patients. Ann. Gastroenterol. Surg. 2019, 3, 496-505. [CrossRef]

39. Bakkers, C.; Lurvink, R.J.; Rijken, A.; Nienhuijs, S.W.; Kok, N.F.; Creemers, G.J.; Verhoef, C.; Lemmens, V.E.; van Erning, F.N.; De Hingh, I.H. Treatment Strategies and Prognosis of Patients With Synchronous or Metachronous Colorectal Peritoneal Metastases: A Population-Based Study. Ann. Surg. Oncol. 2021, in press.

40. Rijken, A.; Bakkers, C.; van Erning, F.N.; van der Geest, L.G.; de Vos-Geelen, J.; Besselink, M.G.; Lemmens, V.E.; de Hingh, I.H.J.T. Incidence, Treatment, and Survival of Synchronous Peritoneal Metastases in Pancreatic Cancer: Update of a Nationwide Cohort. Pancreas 2021, in press. [CrossRef]

41. Burg, L.; Timmermans, M.; Van Der Aa, M.; Boll, D.; Rovers, K.; De Hingh, I.; Van Altena, A. Incidence and predictors of peritoneal metastases of gynecological origin: A population-based study in the Netherlands. J. Gynecol. Oncol. 2020, 31 , e58. [CrossRef]

42. Garg, P.K.; Jara, M.; Alberto, M.; Rau, B. The role of Pressurized IntraPeritoneal Aerosol Chemotherapy in the management of gastric cancer: A systematic review. Pleura Peritoneum 2019, 4, 20180127. [CrossRef] 
43. Al-Batran, S.-E.; Homann, N.; Pauligk, C.; Goetze, T.O.; Meiler, J.; Kasper, S.; Kopp, H.-G.; Mayer, F.; Haag, G.M.; Luley, K.; et al. Perioperative chemotherapy with fluorouracil plus leucovorin, oxaliplatin, and docetaxel versus fluorouracil or capecitabine plus cisplatin and epirubicin for locally advanced, resectable gastric or gastro-oesophageal junction adenocarcinoma (FLOT4): A randomised, phase 2/3 trial. Lancet 2019, 393, 1948-1957.

44. Park, S.; Lim, D.; Sohn, T.; Lee, J.; Zang, D.; Kim, S.; Kang, J.; Oh, S.; Hwang, I.; Ji, J.; et al. A randomized phase III trial comparing adjuvant single-agent S1, S-1 with oxaliplatin, and postoperative chemoradiation with S-1 and oxaliplatin in patients with node-positive gastric cancer after D2 resection: The ARTIST 2 trial. Ann. Oncol. 2021, 32, 368-374. [CrossRef]

45. Zhang, X.; Liang, H.; Li, Z.; Xue, Y.; Wang, Y.; Zhou, Z.; Yu, J.; Bu, Z.; Chen, L.; Du, Y.; et al. Perioperative or postoperative adjuvant oxaliplatin with S-1 versus adjuvant oxaliplatin with capecitabine in patients with locally advanced gastric or gastrooesophageal junction adenocarcinoma undergoing D2 gastrectomy (RESOLVE): An open-label, superiority and non-inferiority, phase 3 randomised controlled trial. Lancet Oncol. 2021, 22, 1081-1092.

46. Kim, J.H.; Lee, H.H.; Seo, H.S.; Jung, Y.J.; Park, C.H. Stage-specific difference in timing and pattern of initial recurrence after curative surgery for gastric cancer. Surg. Oncol. 2019, 30, 81-86. [CrossRef] [PubMed] 